\title{
JNK suppression is essential for $17 \beta$-Estradiol inhibits prostaglandin E2-Induced UPA and MMP- 9 expressions and cell migration in human LoVo colon cancer cells
}

Hsi-Hsien Hsu ${ }^{1,2}$, Wei-Syun Hu ${ }^{3,4}$, Yueh-Min Lin" ${ }^{5,6}$, Wei-Wen Kuo ${ }^{7}$, Li-Mien Chen ${ }^{8}$, Wei-Kung Chen ${ }^{9}$, Jin-Ming Hwang ${ }^{10}$, Fuu-Jen Tsai ${ }^{9}$, Chung-Jung Liu ${ }^{12,13+}$ and Chih-Yang Huang ${ }^{11,14,15^{*}+}$

\begin{abstract}
Background: Epidemiological studies demonstrate that the incidence and mortality rates of colorectal cancer in women are lower than in men. However, it is unknown if $17 \beta$-estradiol treatment is sufficient to inhibit prostaglandin E2 (PGE2)-induced cellular motility in human colon cancer cells.

Methods: We analyzed the protein expression of urokinase plasminogen activator (UPA), tissue plasminogen activator (tPA), matrix metallopeptidases (MMPs), plasminogen activator inhibitor-1 (PAl-1) and tissue inhibitor of metalloproteinases (TIMPs), and the cellular motility in PGE2-stimulated human LoVo cells. 17ß-Estradiol and the inhibitors including LY294002 (Akt activation inhibitor), U0126 (ERK1/2 inhibitor), SB203580 (p38 MAPK inhibitor), SP600125 (JNK1/2 inhibitor), QNZ (NF $\kappa$ B inhibitor) and ICI 182780 were further used to explore the inhibitory effects of $17 \beta$-estradiol on PGE2-induced LoVo cell motility. Student's t-test was used to analyze the difference between the two groups.

Results: Upregulation of urokinase plasminogen activator (UPA), tissue plasminogen activator (tPA) and matrix metallopeptidases (MMPs) is reported to associate with the development of cancer cell mobility, metastasis, and subsequent malignant tumor. After administration of inhibitors including LY294002, U0126, SB203580, SP600125 or QNZ, we found that PGE2 treatment up-regulated UPA and MMP-9 expression via JNK1/2 signaling pathway, thus promoting cellular motility in human LoVo cancer cells. However, PGE2 treatment showed no effects on regulating expression of tPA, MMP-2, plasminogen activator inhibitor-1 (PAl-1), tissue inhibitor of metalloproteinase-1, $-2,-3$ and -4 (TIMP-1, $-2,-3$ and -4 ). We further observed that 173-estradiol treatment inhibited PGE2-induced UPA, MMP9 and cellular motility by suppressing activation of JNK1/2 in human LoVo cancer cells.
\end{abstract}

Conclusions: Collectively, these results suggest that $17 \beta$-estradiol treatment significantly inhibits PGE2-induced motility of human LoVo colon cancer cells.

\section{Background}

Colorectal carcinoma (CRC) is one of the most prevalent cancers world-wide [1], and is the secondary leading cause of cancer-related mortality in the developed countries [2]. Colon cancer accounts for more than 130,000 new cases per year [3] and causes more than 56,000

\footnotetext{
* Correspondence: cyhuang@mail.cmu.edu.tw

+ Contributed equally

${ }^{11}$ Department of Pediatrics, Medical Research and Medical Genetics, China Medical University, Taichung, Taiwan

Full list of author information is available at the end of the article
}

deaths per year in United States [4] despite the advanced chemotherapeutic treatments.

Degradation of extracellular matrix (ECM) is closely associated the development of malignant tumor. ECM degradation by extracellular proteinases accelerates the progress of tumor cell invasion and metastasis [5]. The proteolytic proteinase systems primarily responsible for ECM degradation in vivo are matrix metalloproteinase (MMPs) and plasminogen activator (PA) systems $[5,6]$. Matrix metalloproteinases (MMPs) are a family of

\section{Ciomed Central}


functionally related zinc-containing enzymes that include interstitial collagenases, gelatinases, stromelysin, matrilysin, metalloelastase, and membrane-type MMPs $[7,8]$. Upregulation of MMP-2 and MMP-9 has been shown to play a key role in the progression, invasion, metastasis of colorectal cancer in animal models and patients [9]. MMP activity is closely controlled by physiological inhibitors, TIMPs including TIMP-1, -2, -3 and -4 [10]. Another proteolytic plasminogen system with its plasminogen activators (PA), such as urokinasetype plasminogen activators (UPA) and tissue-type plasminogen activators (tPA) is showed to activate MMPs and to be involved in colon cancer progression [11]. Upregulation of uPA and $\mathrm{PPA}$ is considered as a marker of several types of malignant cancer including colon cancer [12].

Epidemiological studies demonstrate that the incidence and mortality rates of colorectal cancer in women are lower than in men [13]. Estrogen $\left(E_{2}\right)$ performs the profound effects on target tissue is mediated by two estrogen receptor (ER) subtypes ER $\alpha$ and ER $\beta$ [14]. ER $\alpha$ and $\operatorname{ER} \beta$ have been identified in colon tissue in both sexes [15]. In observational studies, estrogen exerts a protective role against the development of fatal colon cancer with a substantially decreased risk in women receiving hormone replacement therapy (HRT) [16-18], and a reduced mortality from this disease [19]. However, the precise mechanism behind protective effects of $17 \beta$ estradiol against PGE2-induced progression in colon cancer remains unclear. In the present study, we examined the effects of $17 \beta$-estradiol on PGE2-induced cellular motility in human LoVo colon cancer cells, and further identified the precise molecular and cellular mechanisms behind this protective property. The results demonstrated that $17 \beta$-estradiol treatment inhibits PGE2-induced cellular motility and expression of uPA and MMP-9 by suppressing the activation of JNK $1 / 2$ in LoVo cells. The present study suggests that $17 \beta$-estradiol presents the properties of anti-cancer by inhibiting PGE2-induced migration in human LoVo cancer cells.

\section{Materials and Methods}

\section{Cells, Antibodies, Reagents and Enzymes}

Human colon cancer cell lines, LoVo, were obtained from the American Tissue Culture Collection (ATCC) (Rockville, MD, USA). LoVo cells were established from the metastatic nodule resected from a 56-year-old colon adenocarcinoma patient. $17 \beta$-estradiol $\left(\mathrm{E}_{2}\right)$ and hydroxyurea were purchased from Sigma (Sigma Chemical Co., St. Louis, Missouri, USA). Prostaglandins E2 (PGE2) was purchased from CALBIOCHEM (Darmstadt, Germany). The LY294002 (PI3K inhibitor), U0126 (MEK1/2 inhibitor), SB203680 (p38 MAPK inhibitor), SP600125 (JNK inhibitor), and ER antagonist ICI
182,780 (ICI) were purchased from TOCRIS (Ellisville, Missouri, USA). 6-Amino-4-(4-phenoxyphenylethylamino) quinazoline (QNZ), NF $\kappa \mathrm{B}$ activation inhibitor was purchased from Peptides International (Louisville, Kentucky, USA). We utilized the following antibodies against JNK1/2, phospho-JNK1/2, uPA, tPA, PAI-1, MMP-2, MMP-9, TIMP-1, TIMP-2, TIMP-3 and TIMP4 (Santa Cruz Biotechnology, Inc. Santa Cruz, California, USA); $\alpha$-tubulin (Lab Vision Corporation, Fremont, California, USA) as loading control. Goat anti-mouse IgG antibody conjugated to horseradish peroxidase and goat anti-rabbit IgG antibody conjugated to horseradish peroxidase and rabbit anti-goat IgG horseradish peroxidase conjugate were purchased from Santa Cruz Biotechnology, Inc. in California, USA.

\section{Cell Culture}

LoVo colon cancer cell line from the American Type Culture Collection (ATCC) (Rockville, MD) were cultured on $100-\mathrm{mm}$ or $60-\mathrm{mm}$ culture dishes in Dulbecco's modified Eagle's medium (DMEM) supplemented with $100 \mu \mathrm{g} / \mathrm{ml}$ penicillin, $100 \mu \mathrm{g} / \mathrm{ml}$ streptomycin, 2 mM glutamine, $1 \mathrm{mM}$ HEPS buffer, and 10\% Clontech fetal bovine serum in humidified air $\left(5 \% \mathrm{CO}_{2}\right)$ at $37^{\circ} \mathrm{C}$

\section{Immunoblotting}

To isolate total proteins, cultured LoVo cells were washed with cold PBS and resuspended in lysis buffer (50 mM Tris, pH 7.5, 0.5 M NaCl, 1.0 mM EDTA, pH 7.5, 10\% glycerol, $1 \mathrm{mM}$ BME, 1\% IGEPAL-630 and a proteinase inhibitor cocktail (Roche Molecular Biochemicals)). After incubation for $30 \mathrm{~min}$ on ice, the supernatant was collected by centrifugation at $12000 \mathrm{~g}$ for 15 min at $4^{\circ} \mathrm{C}$, and the protein concentration was determined by the Bradford method. Sample containing equal proteins $(60 \mu \mathrm{g})$ were loaded and analyzed by Western blot analysis. Briefly, proteins were separated by $12 \%$ SDS-PAGE and transferred onto PVDF membrane (Millipore, Belford, Massachusetts, USA). Membrane were blocked with blocking buffer ( $5 \%$ non-fat dry milk, $20 \mathrm{mM}$ Tris- $\mathrm{HCl}, \mathrm{pH}$ 7.6, $150 \mathrm{mM} \mathrm{NaCl}$, and $0.1 \%$ Tween 20 ) for at least $1 \mathrm{~h}$ at room temperature. Membranes were incubated with primary antibodies in the above solution on an orbit shaker at $4^{\circ} \mathrm{C}$ overnight. Following primary antibody incubation, membranes were incubated with horseradish peroxidase-linked secondary antibodies (anti-rabbit, anti-mouse, or anti-goat IgG).

\section{Migration Assay}

Migration assay was performed using the 48-well Boyden chamber (Neuro Probe) plate with the $8-\mu \mathrm{m}$ pore size polycarbonate membrane filters [20]. The lower compartment was filled with DMEM containing $20 \%$ 
FCS. LoVo cells were placed in the upper part of the Boyden chamber containing serum-free medium and incubated for $48 \mathrm{~h}$. After incubation, the cells on membrane filter were fixed with methanol and stained with $0.05 \%$ Giemsa for $1 \mathrm{~h}$. The cells on upper surface of the filter were removed with a cotton swab. The filters were then rinsed in double distilled water until additional stain was leached. The cells then were air-dried for 20 min. The migratory phenotypes were determined by counting the cells that migrated to the lower side of the filter with microscopy at $200 \times$ and $400 \times$ magnification, respectively. The fourth fields were counted for each filter, and each sample was assayed in triplicate.

\section{Statistical Analysis}

Each experiment was duplicated at least three times. Results were presented as the mean $\pm \mathrm{SE}$, and statistical comparisons were made using the Student's $t$ test. Significance was defined at the $\mathrm{p}<0.05$ or 0.01 levels.

\section{Results}

The Effects of Prostaglandin E2 on Expression of uPA, tPA, MMP-2 and MMP-9 in Human LoVo Colon Cancer Cells

We detected the expression of cellular migration-regulating factors such as urokinase-type plasminogen activators (uPA), tissue-type plasminogen activators (tPA), matrix metalloproteinases-2 and -9 (MMP-2 and -9) in LoVo cells. Activation of proteolytic plasminogen system with $\mathrm{t}-\mathrm{PA}$ and $\mathrm{u}-\mathrm{PA}$ is shown to be involved in upregulation of MMPs [6]. In the present study, we observed that the significant increase in expression levels of uPA (Figure 1A) and MMP-9 (Figure 1B) was induced following PGE2 $\left(10^{-6} \mathrm{M}\right)$ treatment within $3 \mathrm{~h}$, and was maintained up for $24 \mathrm{~h}$. The quantitative results showed that uPA was significantly increased by approximately 2.47 -fold within $3 \mathrm{~h}$, 2.32-fold within $6 \mathrm{~h}, 2.75$-fold within $12 \mathrm{~h}$, and 2.48-fold within 24 h. MMP-9 was significantly increased by approximately 2.27 -fold within $3 \mathrm{~h}, 2.52$-fold within $6 \mathrm{~h}$, 2.65 -fold within $12 \mathrm{~h}$, and 2.79-fold within $24 \mathrm{~h}$. However, PGE2 treatment showed no effects on protein expression of tPA and MMP-2.

The Effects of Prostaglandin E2 on the Expression of PAI1 and TIMPs in Human LoVo Colon Cancer Cells UPA and tPA is closely controlled by PAI-1. In addition, activation of MMP-2 and MMP-9 was inhibited by TIMPs, therefore we further examined whether the expression of PAI-1 and TIMPs including TIMP-1, -2, -3, and -4 was reduced by PGE2 treatment. As shown in Figure 2, LoVo cells were treated with PGE2 $\left(10^{-6} \mathrm{M}\right)$ for various periods ( $3 \mathrm{~h}, 6 \mathrm{~h}, 12 \mathrm{~h}$ and $24 \mathrm{~h}$ ), and subsequently subjected to immunoblotting assay. We observed that

\section{A}
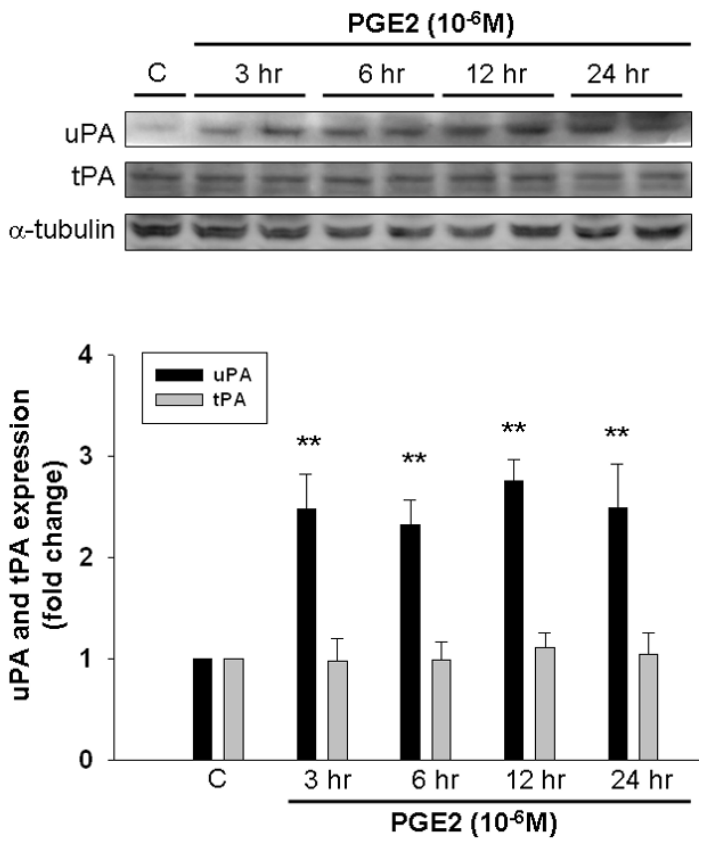

B
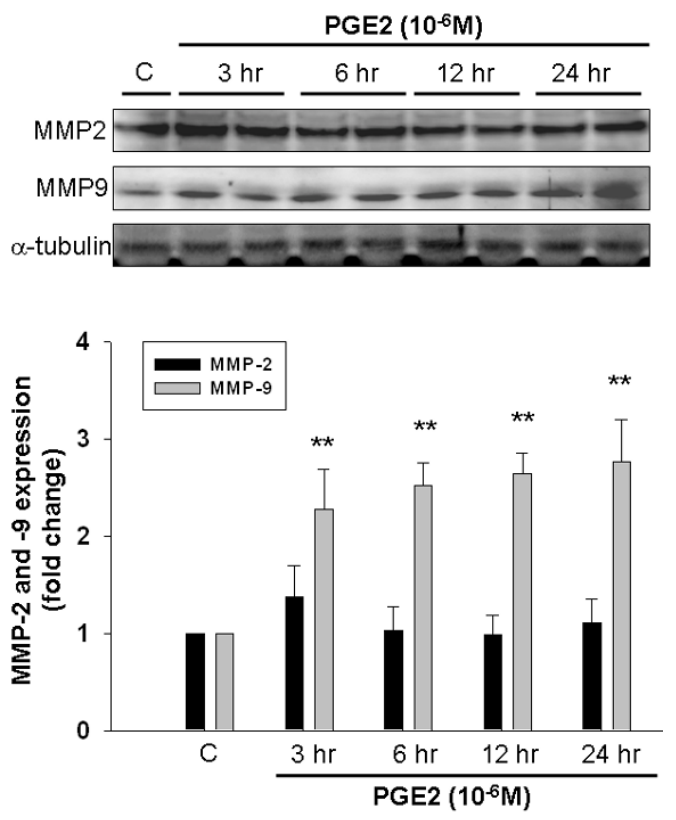

Figure 1 PGE2 induces expression of UPA and MMP-9 in human LoVo colon cancer cells. LoVo cells cultured in DMEM were treated with PGE2 $\left(10^{-6} \mathrm{M}\right)$ for $3 \mathrm{~h}, 6 \mathrm{~h}, 12 \mathrm{~h}$ and $24 \mathrm{~h}$, and subsequently observed protein level of UPA, TPA (A), MMP-2 and MMP-9 (B) in LoVo cells by immunoblotting assay. The responses to different time periods of PGE2 treatment were measured by the immunoblotting assay. ${ }^{* *}, p<0.01$ versus control (mean $\pm S E, n=3$ ). 


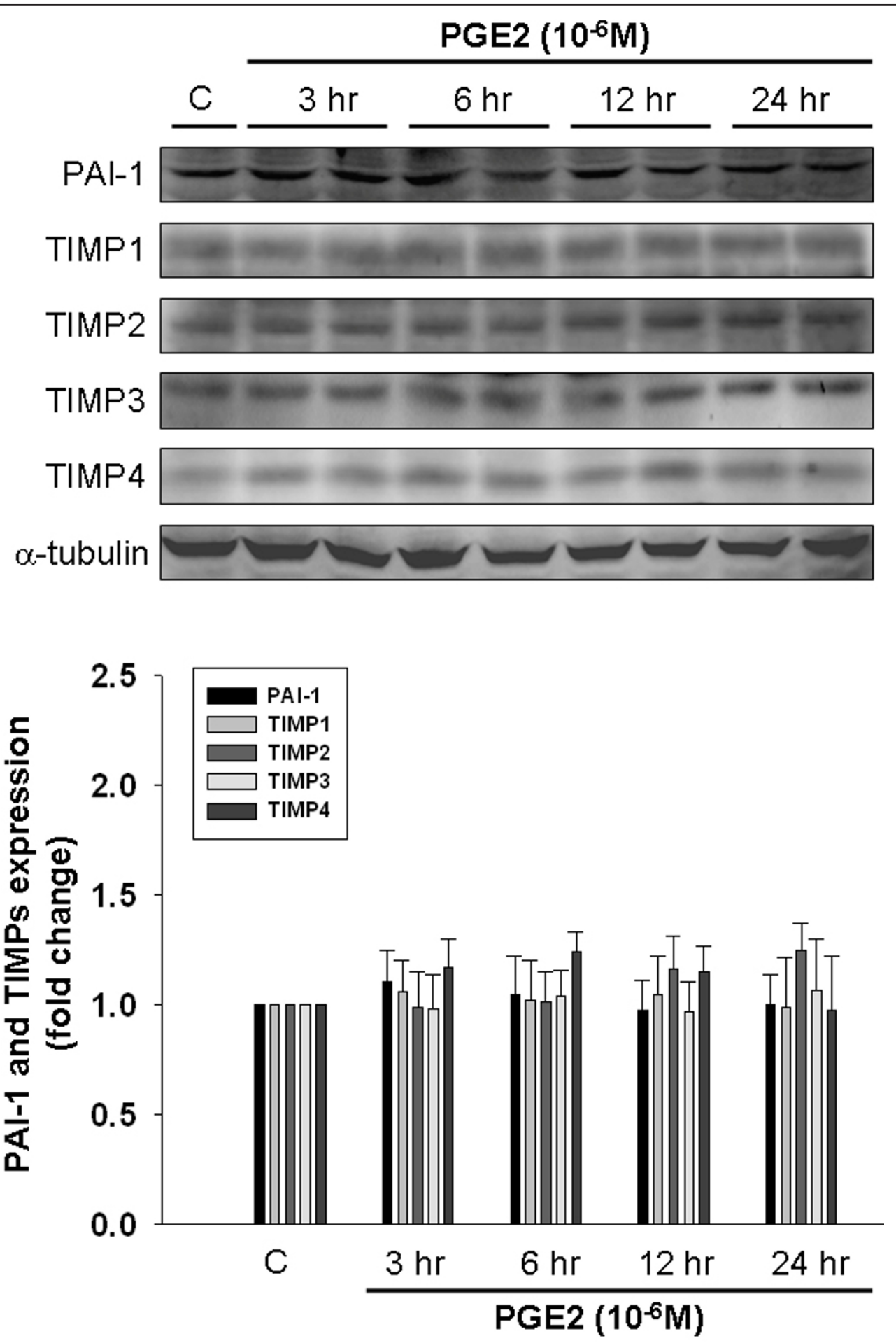

Figure 2 The effect of PGE2 on the expression of PAI-1 and TIMPs in human LoVo colon cancer cells. LoVo cells cultured in DMEM were treated with PGE2 $\left(10^{-6} \mathrm{M}\right)$ for $3 \mathrm{~h}, 6 \mathrm{~h}, 12 \mathrm{~h}$ and $24 \mathrm{~h}$, and then were harvested and lysed. Total protein of cell extracts was separated by $12 \%$ SDS-PAGE, transferred to PVDF membranes, and immunoblotted with antibodies against proteins as indicated. Equal loading was assessed with an anti- $\alpha$-tubulin antibody. 
PGE2 shows no influence on the expression of PAI-1, TIMP-1, $-2,-3$, and -4 in human LoVo cells.

\section{JNK1/2 Mediates PGE2-Upregulated UPA and MMP-9 in Human LoVo Colon Cancer Cells}

To further identify which signal transduction pathway(s) was involved in the mechanism behind PGE2-upregulated expression of UPA and MMP-9 in human colon cancer cells, we applied the following inhibitors such as LY294002 (Akt activation inhibitor), U0126 (ERK1/2 activation inhibitor), SB203580 (p38 MAPK inhibitor), SP600125 (JNK1/2 inhibitor), and QNZ (NF $\kappa$ B activation inhibitor) to respectively block these pathways, followed by the administration of PGE2. LoVo cells were preincubated with LY294002 $(1 \mu \mathrm{M})$, U0126 $(1 \mu \mathrm{M})$, SB203580 $(1 \mu \mathrm{M})$, SP600125 $(1 \mu \mathrm{M})$ or QNZ $(1 \mu \mathrm{M})$ for $1 \mathrm{~h}$ and followed by the administration of PGE2 $(1 \mu \mathrm{M})$ for $24 \mathrm{~h}$, and subsequently were subjected to immunoblotting assay to assess the effect of these inhibitors on PGE2-induced expression of uPA and MMP-9. We observed that PGE2-induced expression of uPA and MMP-9 was significantly inhibited by JNK1/2 inhibitor, SP600125, in LoVo cells. The results suggested that PGE2 upregulates expression of UPA and MMP-9 via JNK1/2 signaling pathway in human LoVo colon cancer cells (Figure 3A).

To further explore the effects of PGE2 on activation of JNK1/2 in human LoVo colon cancer cells, we treated LoVo cells with PGE2 $\left(10^{-6} \mathrm{M}\right)$ for various time periods (15 min, $30 \mathrm{~min}, 1 \mathrm{~h}, 3 \mathrm{~h}, 6 \mathrm{~h}, 12 \mathrm{~h}$ and $24 \mathrm{~h}$ ), and subsequently measured the phosphorylation/activation of proteins by immunoblotting assay. Phosphorylation of JNK1/2 was significantly induced within $15 \mathrm{~min}$ in response to PGE2 stimulation, and was maintained up for $24 \mathrm{~h}$ (Figure $3 \mathrm{~B}$ ). The findings suggested that administration of PGE2 may induce the motility of human colon cancer by inducing the activation of JNK1/2.

\section{7 $\beta$-Estradiol Inhibits PGE2-Induced Expression of UPA and MMP-9 by Suppressing Activation of JNK1/2}

In the present study, we treated LoVo cells with $17 \beta$ estradiol $\left(10^{-8} \mathrm{M}\right)$ for various time periods ( $5 \mathrm{~min}, 15 \mathrm{~min}$, $30 \mathrm{~min}, 1 \mathrm{~h}, 3 \mathrm{~h}, 6 \mathrm{~h}, 12 \mathrm{~h}$ and $24 \mathrm{~h}$ ), and subsequently measured the phosphorylation/activation of proteins by immunoblotting assay. The results show that phosphorylation of JNK1/2 was significantly reduced within $5 \mathrm{~min}$ in response to $17 \beta$-estradiol stimulation, and was maintained up for $24 \mathrm{~h}$ (Figure 4A). We further examined whether $17 \beta$-estradiol inhibits PGE2-induced expression of UPA and MMP-9, and identified the related precise/ molecular mechanism in LoVo cells. LoVo cells were pretreated with $17 \beta$-estradiol $\left(10^{-8} \mathrm{M}\right)$ for $30 \mathrm{~min}$, followed by PGE2 $\left(10^{-6} \mathrm{M}\right)$ treatment for $30 \mathrm{~min}$ or $24 \mathrm{~h}$, and then were subjected to immunoblotting assay for protein detection of phospho-JNK1/2, uPA and MMP-9, respectively. We observed that $17 \beta$-estradiol treatment significantly inhibits PGE-induced activation of JNK1/2 within $30 \mathrm{~min}$, and suppressed PGE2-induced expression of uPA and MMP-9 within $24 \mathrm{~h}$ in human LoVo colon cancer cells (Figure 4B).

\section{$17 \beta$-Estradiol Inhibits PGE2-Induced Cell Migration in Human LoVo Colon Cancer Cells}

In the present study, we examined the effects of PGE2 on the migration ability in human LoVo colon cancer cells by culturing LoVo cells with PGE2 $\left(10^{-6} \mathrm{M}\right)$ in the presence or absence of JNK1/2 inhibitor (SP600125) for $48 \mathrm{~h}$. Subsequently, we observed the ability of motility in LoVo cells by migration assay. Because DNA synthesis was completely inhibited by hydroxyurea $(2 \mathrm{mM})$, a ribonucleotide reductase inhibitor, present in the medium, the elevated level in cell migration could not be ascribed to the increased potential of cell proliferation. In migration assay (Figure 5), we observed that PGE2 induced a significant increase in cellar migration in LoVo cells. A significant increase of cell migration about 83.78\% following PGE2 treatment $\left(10^{-6} \mathrm{M}\right)$ for $48 \mathrm{~h}$ was observed in human LoVo cancer cells. However, SP600125 significantly blocked PGE2-induced cell migration about $70.27 \%$ when compared with PGE2treated group. In addition, pretreatment of $17 \beta$-estradiol $\left(10^{-8} \mathrm{M}\right)$ significantly inhibited PGE2-promoted LoVo cancer cell migration. ICI 182780 treatment further confirmed the inhibitory property of $17 \beta$-estradiol/estrogen receptor (ER) complex on LoVo cellular motility by suppressing function of ERs. These findings suggested that $17 \beta$-estradiol might inhibit PGE2-promoted cellular motility by suppressing activation of JNK1/2 in human LoVo colon cancer cells.

\section{Discussion}

The major findings of the present study can be summarized as followings: (1) PGE2 treatment significantly induced phosphorylation of JNK1/2 in human LoVo colon cancer cells. (2) Migration of LoVo colon cancer cells was significantly promoted by PGE2 $\left(10^{-6} \mathrm{M}\right)$ treatment. We simultaneously observed that an increase in cell migration was accompanied with the upregulation of migration-related factors including uPA and MMP-9, following PGE2 $\left(10^{-6} \mathrm{M}\right)$ treatment. In addition, JNK1/2 mediated PGE2-induced expression of UPA and MMP-9 in LoVo cells. (3) However, PGE2 $\left(10^{-6} \mathrm{M}\right)$ treatment showed no influences on regulating the expression of PAI-1, TIMP-1, TIMP-2, TIMP-3 and TIMP-4 in LoVo cells. (4) PGE2-induced expression of uPA and MMP-9 in human LoVo cells was significantly inhibited by $17 \beta-$ estradiol $\left(10^{-8} \mathrm{M}\right)$ pretreatment. $17 \beta$-Estradiol significantly inhibited PGE2-induced UPA and MMP-9 


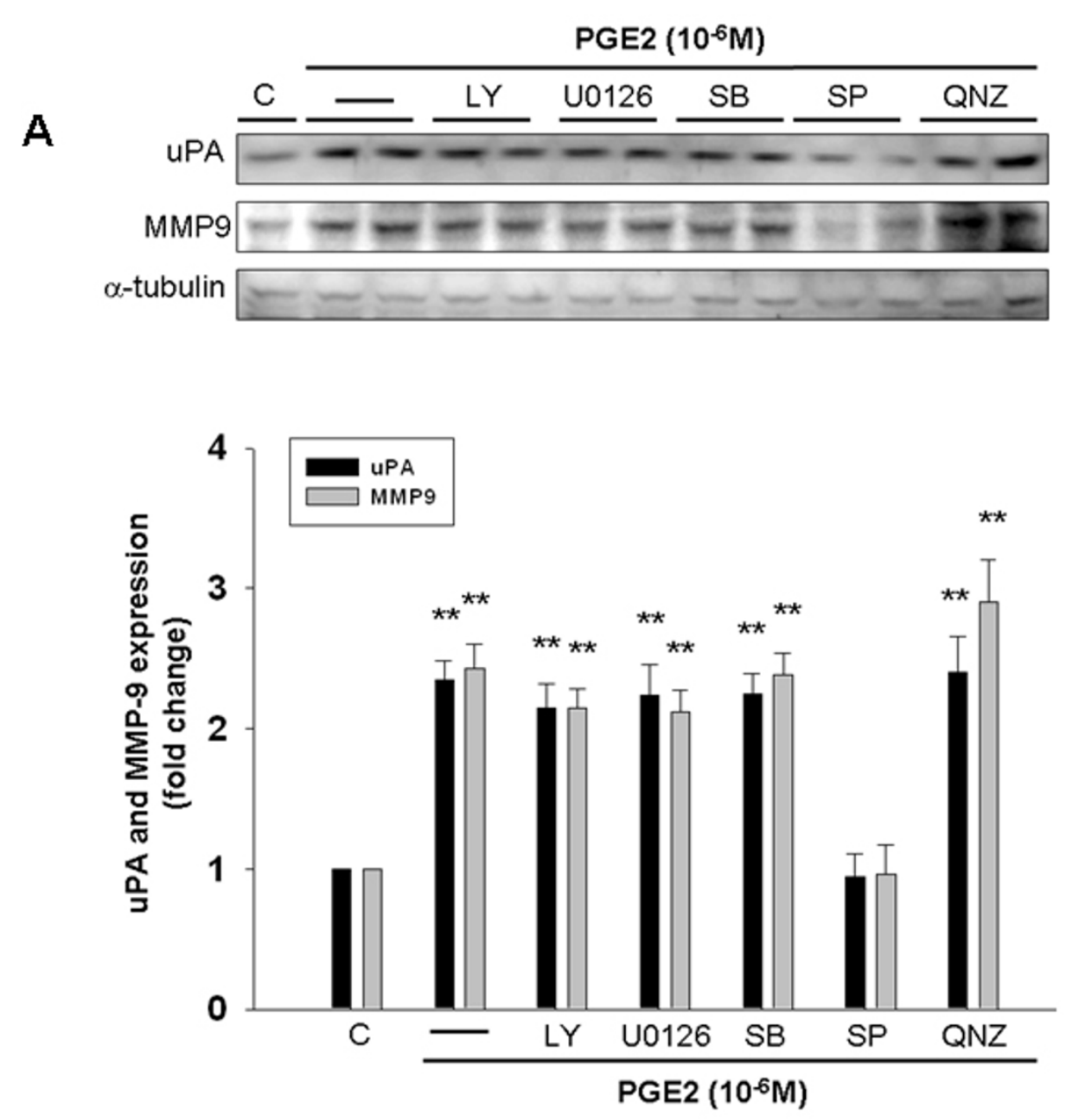

B

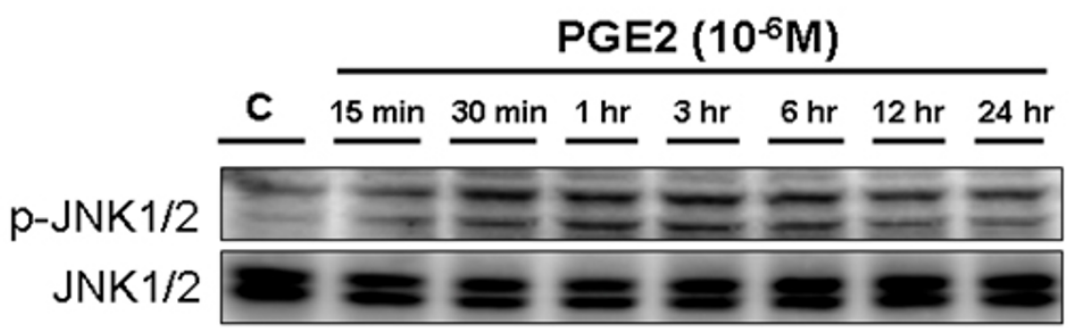

Fold $1.00,1.43,2.55,2.67,2.56,2.542 .29,2.74$

Figure 3 PGE2 upregulates uPA and MMP-9 via JNK1/2 signaling pathway in human LoVo colon cancer cells. (A) LoVo cells were

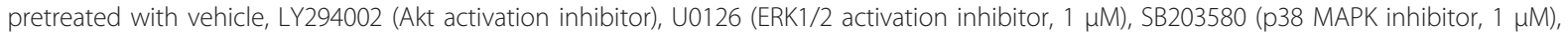
SP600125 (JNK1/2 inhibitor, $1 \mu \mathrm{M}$ ) or QNZ (NF $\kappa$ B inhibitor, $1 \mu \mathrm{M}$ ) for $1 \mathrm{~h}$ and followed by PGE2 $\left(10^{-6} \mathrm{M}\right)$ administration for $24 \mathrm{~h}$, and then were harvested for immunoblotting assays. (B) LoVo cells cultured in DMEM were treated with PGE2 $\left(10^{-6} \mathrm{M}\right)$ for various periods (15 min, $30 \mathrm{~min}, 1 \mathrm{~h}, 3$ $\mathrm{h}, 6 \mathrm{~h}, 12 \mathrm{~h}$ and $24 \mathrm{~h}$ ), and subsequently measured the phosphorylation/activation of proteins by immunoblotting assay. The fold ratio of $\mathrm{p}-$ JNK1/2 and JNK1/2 was measured. Total protein of cell extracts was separated by $12 \%$ SDS-PAGE, transferred to PVDF membranes, and immunoblotted with antibodies against UPA, MMP-9 (A), phospho-JNK1/2 and JNK1/2 (B) proteins. Equal loading was assessed with an anti- $\alpha-$ tubulin antibody. ${ }^{* *}, p<0.01$ versus control (mean $\pm S E, n=3$ ). 
A

$\mathrm{E} 2\left(10^{-8} \mathrm{M}\right)$

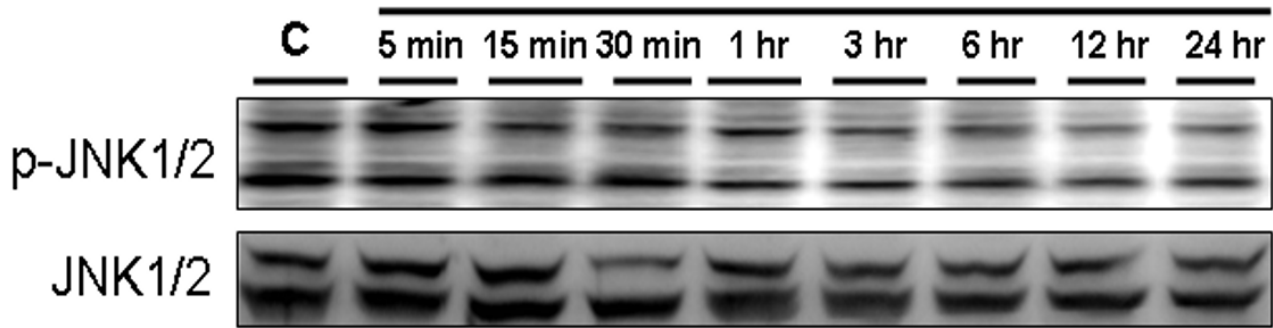

Fold $1.00,0.85,0.74,0.68,0.54,0.44,0.47,0.42,0.46$

B
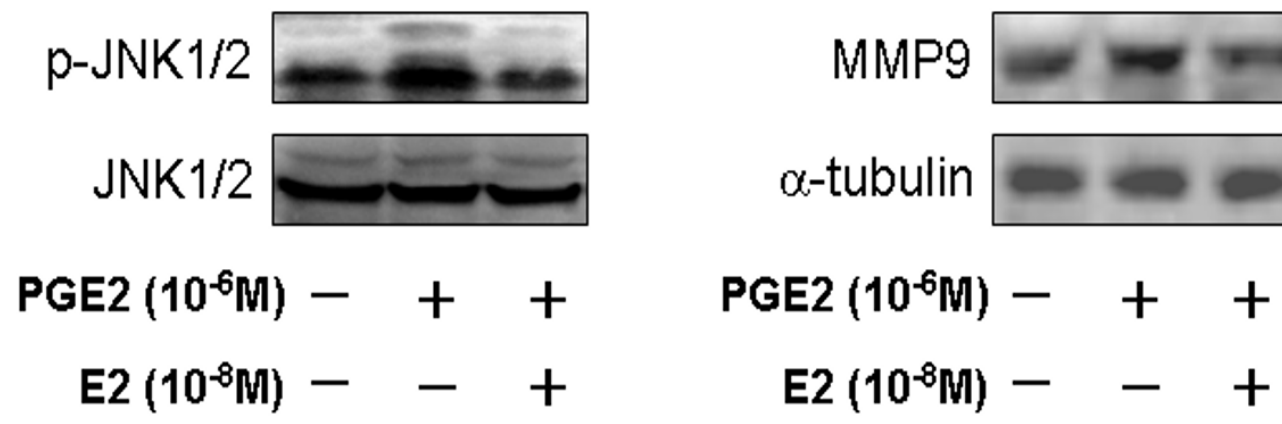

Figure 4 17 $\beta$-Estradiol down-regulates PGE2-induced UPA and MMP-9 expression by suppressing activation of JNK1/2 in human LoVo cells. (A) LoVo cells cultured in DMEM were treated with $17 \beta$-estradiol $\left(10^{-8} \mathrm{M}\right)$ for various periods $(5 \mathrm{~min}, 15 \mathrm{~min}, 30 \mathrm{~min}, 1 \mathrm{~h}, 3 \mathrm{~h}, 6 \mathrm{~h}, 12 \mathrm{~h}$ and $24 \mathrm{~h}$ ), and subsequently measured the phosphorylation/activation of proteins by immunoblotting assay. The fold ratio of p-JNK1/2 and JNK1/2 was measured. (B) LoVo cells were pretreated with $17 \beta$-estradiol $\left(10^{-8} \mathrm{M}\right)$ for $30 \mathrm{~min}$, followed by PGE2 (10-6 M) treatment for 30 min or 24 $\mathrm{h}$, and then were subjected to immunoblotting assay for protein detection of phospho-JNK1/2 (PGE2 stimulation within 30 min); UPA and MMP9 (PGE2 stimulation within $24 \mathrm{~h}$ ).

expression by suppressing activation of JNK1/2. These results demonstrate that $17 \beta$-estradiol may efficiently inhibit PGE2-induced motility in human LoVo colon cancer cells (Figure 6).

Upregulation of MMPs is reported to contribute to ECM remodeling, tumor cell invasion and metastasis, thus leading to the development of malignant tumor [5]. Both mRNA levels MMP-2 and MMP-9 have been found to be overexpressed in colon carcinomas $[21,22]$. In the observations of Collins et al. [23], MMP-2 mRNA is more significantly expressed in tumor lesions than in normal colon tissues. Immunostaining assay showed that MMP-9 expression is more frequently present in advanced tumor stages, and in invasive tumor regions wherein cancer cells are in close proximity of inflammatory cells, suggesting that locally proteolytic and collagenlytic activities contributes to the property of invasion in colorectal cancers [24]. In the stage of cancer development, upregulation of MMP-2 and MMP-9 accelerates cell migration and invasion in colorectal cancer [9], thus resulting in the development of malignant tumor, poor prognosis, and shortening disease-free period and overall survival. Here, we founded that administration of $17 \beta$-estradiol significantly inhibited PGE2-induced cell migration, and downregulated PGE2upregulated expression of MMP-9 in LoVo cells. The findings suggested that $17 \beta$-estradiol may impair PGE2promoted cell motility by inhibiting the expression of MMP-9. 


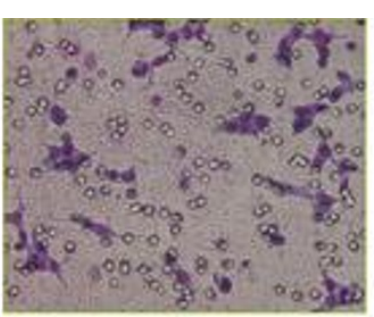

C

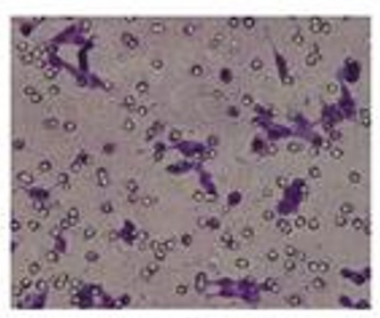

PGE2+E2

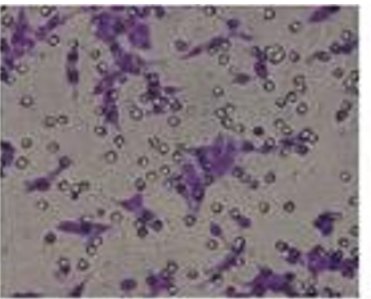

PGE2

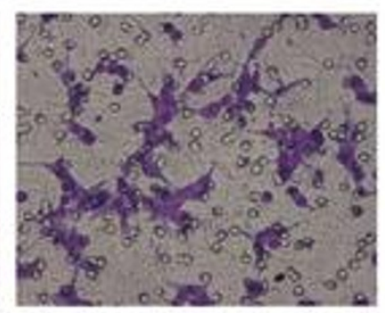

PGE2+E2+ICl

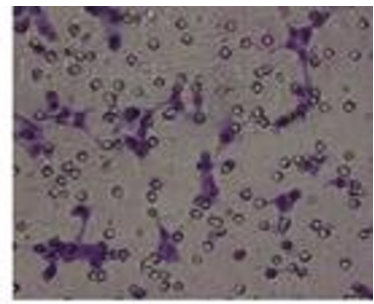

PGE2+SP
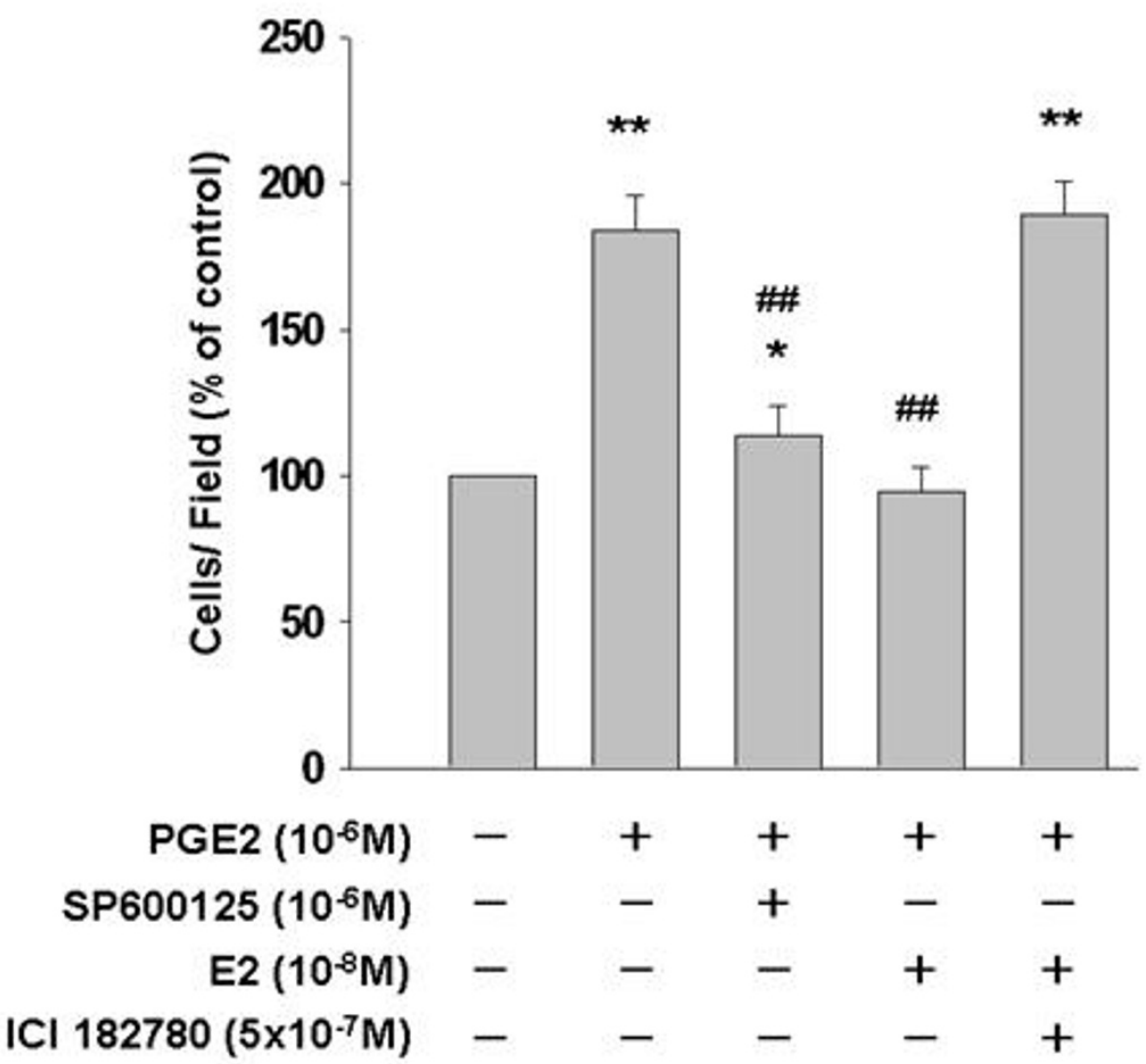

Figure 5 17 $\beta$-estradiol inhibits PGE2-promoted cellular motility in human LoVo cells. LoVo cells were pretreated with vehicle, SP600125 (JNK1/2 inhibitor, $1 \mu \mathrm{M})$ or $17 \beta$-estradiol $\left(10^{-8} \mathrm{M}\right)$ for $1 \mathrm{~h}$ prior to PGE2 $\left(10^{-6} \mathrm{M}\right)$ treatment for another $48 \mathrm{~h}$ in hydroxyurea-containing DMEM, and subsequently observed the ability of migration in LoVo cells by migration assay. At the same time, LoVo cells were treated $17 \beta$-estradiol (10 $\left.{ }^{-8} \mathrm{M}\right)$ in the presence or absence of ERs inhibitor, ICI $182780\left(5 \times 10^{-7} \mathrm{M}\right)$. The responses to different treatments were observed and analysis with a light microscope. * $p<0.05$ versus control; **, $p<0.01$ versus control. \#\#, $p<0.01$ versus PGE2 treatment group (mean $\pm S E, n=4)$. 


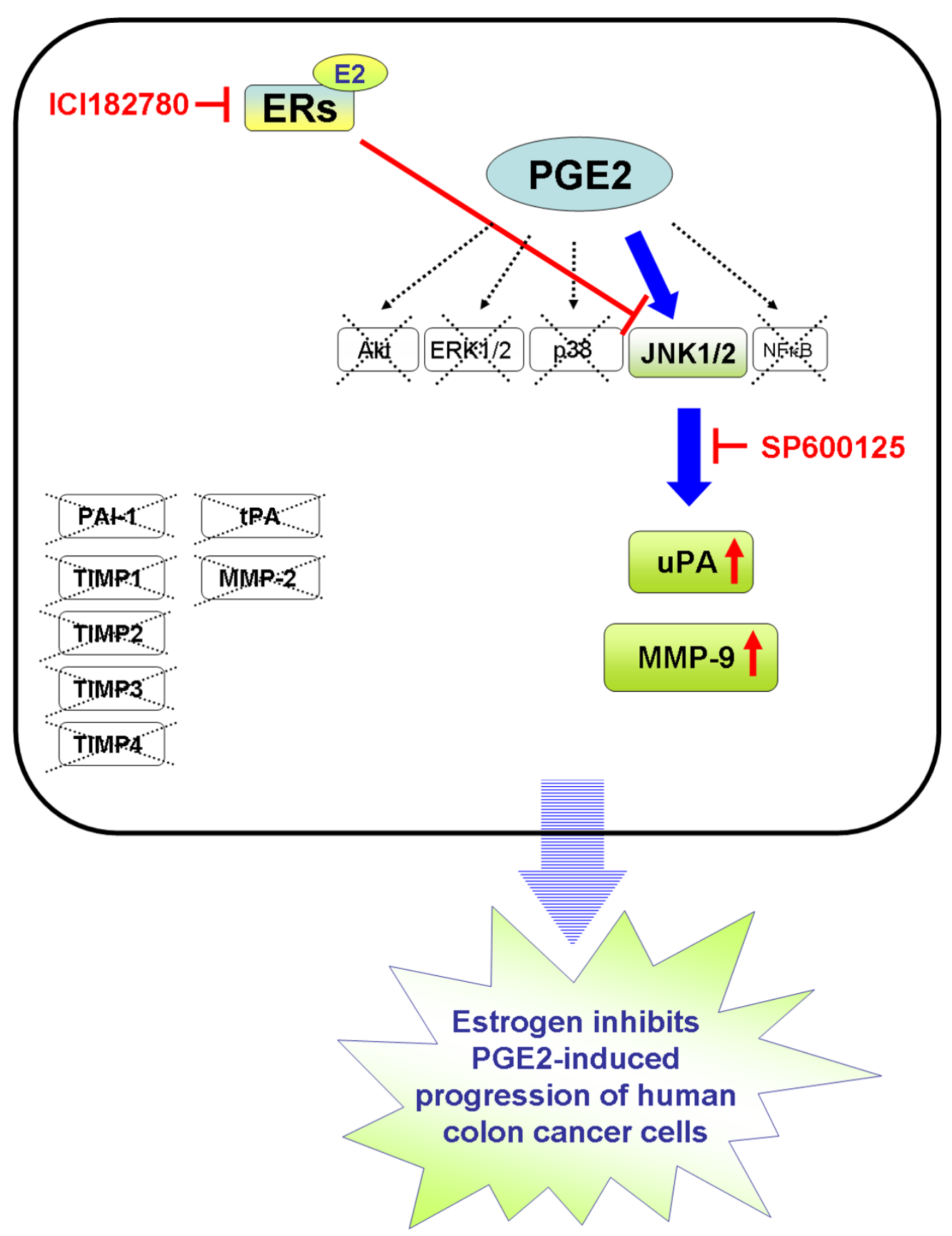

Figure 6 A schematic representation showing 17ß-estradiol inhibition of uPA and MMP-9 expression, and cell motility via suppression of JNK1/2 pathway in human LoVo colon cancer cells. Administration of prostaglandin E2 (PGE2) rapidly activates kinase such as JNK1/2, thus leading to the expression of downstream targets including UPA and MMP-9, which further promotes cellular motility in human LoVo cancer cells. However, PGE2 treatment shows no effects on regulation of TPA, MMP-2, PAI-1 and TIMPS (TIMP-1, TIMP-2, TIMP-3 and TIMP-4). Estrogen

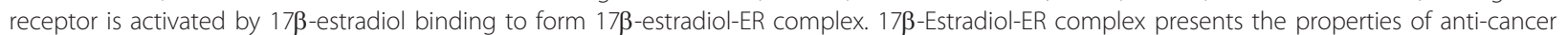
by downregulating expression of UPA amd MMP-9 via deactivation of JNK1/2 in LoVo cells. It suggests that 17ß-estradiol might inhibit PGE2induced motility of human LoVo colon cancer cells.

Another plasminogen activator system (PAS) with upregulation of UPA and tPA is reported to be involved in MMPs activation and colon cancer development $[11,25]$. uPA was significantly greater in tumour tissues than normal tissues [26]. uPA upregulated in colon tumor tissue enhances colorectal cancer invasion and metastasis, and this upregulation in uPA is correlated with Dukes's staging and lymphatic invasion [27]. 
Upregulation in uPA and tPA expression is considered as a marker malignant colon cancer [11,12]. In the present study, we observed that the significant reduction in protein level of uPA was observed after $17 \beta$-estradiol treatment in human colon cancer cells. These findings suggested that downregulation of uPA is involved in $17 \beta$-estradiol-mediated anticancer effects.

Activation of MMPs is regulated by physiological inhibitors TIMPs [28]. TIMPs not only directly inhibit MMPs but also form complexes with MMPs to control activation and stability of MMPs [10,29]. Four different TIMP species have been identified as TIMP-1, TIMP-2, TIMP-3 and TIMP-4. TIMP binds to MMP in a 1:1 stoichiometric ratio. Induction of functional TIMP-3 in TIMP-3-deficient human DLD-1 colon cells shows a growth arrest and inhibits tumor growth in vivo [30]. Injection of AdTIMP-2 into preestablished tumors presents the significant reduced tumor growth rates by approximately $60-80 \%$ and tumor-associated angiogenesis index by approximately $25-75 \%$. Metastasis of LLC tumor was inhibited by $>90 \%$. In addition, AdTIMP-2treated mice showed a significantly prolonged survival [31], which emphasizes the importance of endogenous regulation of MMPs activity by TIMPs. In the present study, we further detected the protein level of TIMPs in human LoVo cancer cells that had been exposed to PGE2, which demonstrated that PGE2 treatment shows no influence on regulating TIMP-1, TIMP-2, TIMP-3 and TIMP-4. The results suggested that PGE2 couldn't promote the motility of colon cancer by down-regulating expressions of TIMPs. In addition, the proteolytic action of uPA and tPA is controlled by plasminogen activator inhibitors 1 and 2 (PAI-1 and PAI-2) [11]. We thus simultaneously examined the expression of PAI-1 in LoVo cells that had been treated with PGE2. However, no influence on PAI-1 expression was observed after PGE2 stimulation.

A large number of studies have been dedicated to exploring the molecular mechanisms involved in the downregulation of cancer development. Mitogen-activated protein kinases (MAPKs) include tree major subfamilies such as the extracellularly responsive kinases (ERKs), the c-Jun $\mathrm{N}$-terminal kinases (JNKs), also known as stress-activated protein kinases (SAPKs), and the p38 MAPKs [32]. Studies have showed that ERK1/2 is involved in hepatoma-derived growth factor-induced promotion of carcinogenesis of gastric epithelial cells [33] and in the proliferation of pancreatic stellate cells [34]. p38 MAPK mediates TNF $\alpha$-induced MMP-9 expression, thus leading to the progression of human urinary bladder cancer cells [35]. JNK/AP-1 signaling pathway may contribute to cellular migration and invasion of prostate cancer cells [36]. Hepatocyte growth factor-activated both Akt and JNK enhance the proteolysis and invasiveness of human nasopharyngeal cancer cells [37]. Abnormal response of NFkB signaling pathway may contribute to the chemoresistance in acute lymphoblastic leukaemia [38]. In the present study, we observed that JNK1/2 signaling pathway mediated expression of UPA and MMP-9 in response to PGE2, which further contributed to cellular motility of human LoVo cancer cells. Previous studies have shown that $17 \beta$-estradiol $\left(\mathrm{E}_{2}\right)$ binding to estrogen receptors (ERs) can regulate tissue/cellular responses through multiple signaling pathways [32]. In the present study, we further observed that $17 \beta$-estradiol pretreatment inhibited PGE2-induced expression of UPA, MMP-9, and cellular motility via suppressing activation of JNK $1 / 2$ in LoVo cells. It suggested that $17 \beta$-estradiol presents the anticancer properties by inhibiting PGE2-promoted motility in human LoVo cancer cells.

Estrogen receptor $\alpha$ and $\beta$ (ER $\alpha$ and $\beta$ ) have been identified in colon tissue $[15,39,40]$. In the normal colon mucosa, there are no significant differences in the protein expression of $E R \alpha$ and $\beta$ between men and women [40]. Epidemiological data on taking home replacement therapy (HRT) suggests that the loss of estrogen inactivation may be an important mechanism in the pathogenesis of colonic cancer [41]. Studies suggest that estrogen exerts a protective role against the development of fatal colon cancer with a substantially decreased risk in women receiving HRT [16-18], and a reduced mortality from this disease [19]. In this study, we observed that $17 \beta$-estradiol reduces PGE2-induced motility of LoVo colon cancer cells derived from male origin. The above study findings strongly suggest that estrogen treatment is an important program against the development of colon cancer.

Estrogen has been reported to modulate the activity of the multiple signaling cascades $[42,43]$ such as the induction of translocation of ER to the cell membrane in MCF-7 cells [44], and then $E_{2} / E R s$ complex interact with caveolin-1/-2 in caveolae regions of the plasma membrane [45] wherein cavelin-1 is associated with signaling molecules, such as $\mathrm{G}$ proteins, growth factor receptors (IGFIR, EGFR), non-growth factor tyrosine kinase (Src, Ras), and linker proteins (MNAR, striatin) $[46,47]$. In addition, membrane ER can activate Src-MMP2/9-EGFRMAPK pathway through Gai protein in breast cancer cells [47], and activate MAPK-dependent endothelial nitric oxide synthase (eNOS) to increase NO production, contributing to the beneficial effects on cardiac cells $[48,49]$. In COS7 cell, cytosolic ER binds to membrane IGF-IR and rapidly activates IGF-IR-Ras-Raf-MAPKKERK1/2 signaling cascade, which in turn activates ER in a positive feedback loop [50]. In the present study, we observed that $17 \beta$-estradiol $\left(10^{-8} \mathrm{M}\right)$ treatment rapidly reduces the phosphorylation of JNK1/2 within $15 \mathrm{~min}$. in 
human LoVo colon cancer cells, which suggests that estrogen-membrane ER complex might majorly reduce PGE2-induced JNK1/2 phosphorylation through nongenomic effect. Previous studies have reported that ER $\beta$ is expressed greater in normal colon tissues than pathologic tissues [51], and that the increased ratio of $E R \alpha$ and $\beta$ due to altered expression of ER subtypes is found in patients with CRC [40], supporting the role of ER $\beta$ as a relevant prognostic biomarker of tumor progression [52]. According to these previous studies, we speculated that $17 \beta$-estradiol might decrease PGE2-induced cellular motility through ER $\beta$ in human LoVo colon cancer cells.

\section{Conclusions}

In summary, we found that PGE2 rapidly activates JNK1/2 kinase, and then increases the protein levels of uPA and MMP-9, which further promotes cellular motility in human LoVo cancer cells. $17 \beta$-Estradiol presents the properties of anti-cancer by downregulating expression of uPA and MMP-9 via deactivation of JNK1/2 in LoVo cells. These results also demonstrate that $17 \beta$ estradiol efficiently inhibit PGE2-induced LoVo cell motility. These findings might explain that why the incidence and mortality rates of colorectal cancer in women are lower than in men; and that estrogen exerts a protective role against the development of fatal colon cancer with a substantially decreased risk in women receiving hormone replacement therapy (HRT) and a reduced mortality from this disease.

\footnotetext{
Abbreviations

E2: 17ß-Estradiol; PGE2: Prostaglandin E2; ERK: extracellular signal regulated kinase; p38 MAPK: p38 mitogen-activated protein kinase; JNK: c-Jun Nterminal kinase; NF-KB: nuclear factor K B; PI3-K: phosphatidylinositol 3-kinase; PKB: protein kinase $B$; UPA: urokinase plasminogen activator; tPA: tissue plasminogen activator; PAl-1: plasminogen activator inhibitor-1; MMP: matrix metallopeptidase; TIMP: tissue inhibitor of metalloproteinases; DMEM: Dulbecco's modified Eagle's medium; QNZ: 6-amino-4-(4phenoxyphenylethylamino) quinazoline; GAPDH: glyceraldehyde-3phosphate dehydrogenase; PBS: phosphate-buffered saline; ECM: extracellular matrix.

\section{Author details}

'Division of Colorectal Surgery, Mackay Memorial Hospital, Taipei, Taiwan. ${ }^{2}$ Mackay Medicine, Nursing and Management College, Taipei, Taiwan. ${ }^{3}$ Division of Cardiology, Taipei Medical University Shuang-Ho Hospital, Taipei, Taiwan. ${ }^{4}$ Graduate Institute of Aging Medicine, China Medical University, Taichung, Taiwan. ${ }^{5}$ School of medicine, Chung Shan Medical University, Taichung, Taiwan. ${ }^{6}$ Department of Medical Technology, Jen-Teh Junior College of Medicine, Nursing and Management, Miaoli, Taiwan. ${ }^{7}$ Department of Biological Science and Technology, China Medical University, Taichung, Taiwan. ${ }^{8}$ Division of Medical Technology, Department of Internal Medicine, Armed-Force, Taichung General Hospital, Taichung, Taiwan. ${ }^{9}$ Emergency Department, China Medical University Hospital, Taichung, Taiwan. ${ }^{10}$ School of Applied Chemistry, Chung Shan Medical University, Taichung, Taiwan. ${ }^{11}$ Department of Pediatrics, Medical Research and Medical Genetics, China Medical University, Taichung, Taiwan. ${ }^{12}$ Division of Gastroenterology, Department of Internal Medicine, Kaohsiung Medical University Hospital, Kaohsiung, Taiwan. ${ }^{13} \mathrm{C} a n c e r$ Center, Kaohsiung Medical University Hospital, Kaohsiung, Taiwan. ${ }^{14}$ Graduate Institute of Basic Medical Science, China
}

Medical University, Taichung, Taiwan. ${ }^{15}$ Department of Health and Nutrition Biotechnology, Asia University, Taichung, Taiwan.

\section{Authors' contributions}

$\mathrm{HHH}$ and WSH performed cell culture with drug dose test. YML and WWK performed Immunoblotting assay. LMC and WKC performed cell motility assay. JMH and FJT performed integrity of the data and the accuracy of the data analysis. CJL performed study concept and design, and wrote the manuscript. CYH performed study supervision. All authors read and approved the final manuscript.

\section{Competing interests}

The authors declare that they have no competing interests.

Received: 5 April 2011 Accepted: 22 August 2011

Published: 22 August 2011

\section{References}

1. Jemal A, Murray T, Ward E, et al: Cancer statistics, 2005. CA Cancer J Clin 2005, 55:10-30.

2. Greenwald P: Colon cancer overview. Cancer 1992, 70:1206-1215.

3. Jemal A, Thomas A, Murray T, et al: Cancer statistics, 2002. CA Cancer I Clin 2002, 52:23-47.

4. Jemal A, Tiwari RC, Murray T, et al: Cancer statistics, 2004. CA Cancer J Clin 2004, 54:8-29.

5. Liotta LA, Stetler-Stevenson WG: Tumor invasion and metastasis: an imbalance of positive and negative regulation. Cancer Res 1991, 51:5054s-5059s.

6. Yoon WH, Jung YJ, Kim TD, et al: Gabexate mesilate inhibits colon cancer growth, invasion, and metastasis by reducing matrix metalloproteinases and angiogenesis. Clin Cancer Res 2004, 10(13):4517-4526.

7. Coussens LM, Fingleton B, Matrisian LM: Matrix metalloproteinase inhibitors and cancer: trials and tribulations. Science 2002, 295(5564):2387-2392.

8. Ellerbroek SM, Stack MS: Membrane associated matrix metalloproteinases in metastasis. Bioessays 1999, 21(11):940-949.

9. Mook OR, Frederiks WM, Van Noorden CJ: The role of gelatinases in colorectal cancer progression and metastasis. Biochim Biophys Acta 2004, 1705(2):69-89.

10. Gomez DE, Alonso DF, Yoshiji $H$, et al: Tissue inhibitors of metalloproteinases: structure, regulation and biological functions. Eur J Cell Biol 1997, 74(2):111-122.

11. Berger DH: Plasmin/plasminogen system in colorectal cancer. World J Surg 2002, 26(7):767-771.

12. Seetoo DQ, Crowe PJ, Russell PJ, et al: Quantitative expression of protein markers of plasminogen activation system in prognosis of colorectal cancer. J Surg Oncol 2003, 82(3):184-193.

13. Jacobs ET, Thompson PA, Martinez ME: Diet, gender, and colorectal neoplasia. J Clin Gastroenterol 2007, 41(8):731-746.

14. Katzenellenbogen JA, Katzenellenbogen BS: Nuclear hormone receptors: ligand-activated regulators of transcription and diverse cell responses. Chem Biol 1996, 3(7):529-536.

15. Campbell-Thompson M, Lynch IJ, Bhardwaj B: Expression of estrogen receptor (ER) subtypes and ERbeta isoforms in colon cancer. Cancer Res 2001, 61(2):632-640.

16. Gambacciani M, Monteleone P, Sacco A, et al: Hormone replacement therapy and endometrial, ovarian and colorectal cancer. Best Pract Res Clin Endocrinol Metab 2003, 17(1):139-147.

17. Grodstein F, Martinez ME, Platz EA, et al: Postmenopausal hormone use and risk for colorectal cancer and adenoma. Ann Intern Med 1998, 128(9):705-712.

18. Chlebowski RT, Wactawski-Wende J, Ritenbaugh C, et al: Estrogen plus progestin and colorectal cancer in postmenopausal women. $N$ Engl J Med 2004, 350(10):991-1004.

19. Calle EE, Miracle-McMahill HL, Thun MJ, et al: Estrogen replacement therapy and risk of fatal colon cancer in a prospective cohort of postmenopausal women. J Natl Cancer Inst 1995, 87(7):517-523.

20. Lai TY, Chen LM, Lin JY, et al: 17beta-estradiol inhibits prostaglandin E2induced COX-2 expressions and cell migration by suppressing Akt and ERK1/2 signaling pathways in human LoVo colon cancer cells. Mol Cell Biochem 2010, 342(1-2):63-70. 
21. Chan CC, Menges M, Orzechowski HD, et al: Increased matrix metalloproteinase 2 concentration and transcript expression in advanced colorectal carcinomas. Int J Colorectal Dis 2001, 16(3):133-140.

22. Roeb E, Dietrich CG, Winograd R, et al: Activity and cellular origin of gelatinases in patients with colon and rectal carcinoma differential activity of matrix metalloproteinase-9. Cancer 2001, 92(10):2680-2691.

23. Collins HM, Morris TM, Watson SA: Spectrum of matrix metalloproteinase expression in primary and metastatic colon cancer: relationship to the tissue inhibitors of metalloproteinases and membrane type-1-matrix metalloproteinase. Br J Cancer 2001, 84(12):1664-1670.

24. Jeziorska M, Haboubi NY, Schofield PF, et al: Distribution of gelatinase B (MMP-9) and type IV collagen in colorectal carcinoma. Int J Colorectal Dis 1994, 9(3):141-148.

25. Zucker S, Vacirca J: Role of matrix metalloproteinases (MMPs) in colorectal cancer. Cancer Metastasis Rev 2004, 23(1-2):101-117.

26. Baker EA, Leaper DJ: The plasminogen activator and matrix metalloproteinase systems in colorectal cancer: relationship to tumour pathology. Eur J Cancer 2003, 39(7):981-988.

27. Baker EA, Bergin FG, Leaper DJ: Plasminogen activator system, vascular endothelial growth factor, and colorectal cancer progression. Mol Pathol 2000, 53(6):307-312.

28. Li YY, McTiernan CF, Feldman AM: Interplay of matrix metalloproteinases, tissue inhibitors of metalloproteinases and their regulators in cardiac matrix remodeling. Cardiovasc Res 2000, 46(2):214-224.

29. Goldberg Gl, Marmer BL, Grant GA, et al: Human 72-kilodalton type IV collagenase forms a complex with a tissue inhibitor of metalloproteases designated TIMP-2. Proc Natl Acad Sci USA 1989, 86(21):8207-8211.

30. Bian J, Wang Y, Smith MR, et al: Suppression of in vivo tumor growth and induction of suspension cell death by tissue inhibitor of metalloproteinases (TIMP)-3. Carcinogenesis 1996, 17(9):1805-1811.

31. Li H, Lindenmeyer F, Grenet C, et al: AdTIMP-2 inhibits tumor growth, angiogenesis, and metastasis, and prolongs survival in mice. Hum Gene Ther 2001, 12(5):515-526.

32. Marino M, Galluzzo P, Ascenzi P: Estrogen signaling multiple pathways to impact gene transcription. Curr Genomics 2006, 7(8):497-508.

33. Mao J, Xu Z, Fang $Y$, et al: Hepatoma-derived growth factor involved in the carcinogenesis of gastric epithelial cells through promotion of cell proliferation by Erk1/2 activation. Cancer Sci 2008, 99(11):2120-2127.

34. Schwer $\mathrm{Cl}$, Guerrero AM, Humar M, et al: Heme oxygenase-1 inhibits the proliferation of pancreatic stellate cells by repression of the ERK1/2 pathway. J Pharmacol Exp Ther 2008, 327(3):863-871.

35. Lee SJ, Park SS, Lee US, et al: Signaling pathway for TNF-alpha-induced MMP-9 expression: Mediation through p38 MAP kinase, and inhibition by anti-cancer molecule magnolol in human urinary bladder cancer 5637 cells. Int Immunopharmacol 2008, 8(13-14):1821-1826.

36. Kwon GT, Cho HJ, Chung WY, et al: Isoliquiritigenin inhibits migration and invasion of prostate cancer cells: possible mediation by decreased JNK/ AP-1 signaling. J Nutr Biochem 2009, 20(9):663-676.

37. Zhou HY, Wan KF, Ip CK, et al: Hepatocyte growth factor enhances proteolysis and invasiveness of human nasopharyngeal cancer cells through activation of PI3K and JNK. FEBS Lett 2008, 582(23-24):3415-3422.

38. Stankovic T, Marston E: Molecular mechanisms involved in chemoresistance in paediatric acute lymphoblastic leukaemia. Srp Arh Celok Lek 2008, 136(3-4):187-192.

39. Mostafaie N, Kallay E, Sauerzapf E, et al: Correlated downregulation of estrogen receptor beta and the circadian clock gene Per1 in human colorectal cancer. Mol Carcinog 2009, 48(7):642-647.

40. Nussler NC, Reinbacher K, Shanny N, et al: Sex-specific differences in the expression levels of estrogen receptor subtypes in colorectal cancer. Gend Med 2008, 5(3):209-217.

41. English MA, Kane KF, Cruickshank N, et al: Loss of estrogen inactivation in colonic cancer. J Clin Endocrinol Metab 1999, 84(6):2080-2085.

42. Yang XP, Reckelhoff JF: Estrogen, hormonal replacement therapy and cardiovascular disease. Curr Opin Nephrol Hypertens 2011, 20:133-138.

43. Liu CJ, Lo JF, Kuo CH, et al: Akt mediates 17beta-estradiol and/or estrogen receptor-alpha inhibition of LPS-induced tumor necresis factoralpha expression and myocardial cell apoptosis by suppressing the JNK1/2-NFkappaB pathway. J Cell Mol Med 2009, 13(9B):3655-3667.

44. Cheskis BJ, Greger JG, Nagpal S, et al: Signaling by estrogens. J Cell Physiol 2007, 213(3):610-617
45. Razandi M, Alton G, Pedram A, et al: Identification of a structural determinant necessary for the localization and function of estrogen receptor alpha at the plasma membrane. Mol Cell Biol 2003, 23(5):1633-1646

46. Hammes SR, Levin ER: Extranuclear steroid receptors: nature and actions. Endocr Rev 2007, 28(7):726-741.

47. Razandi M, Pedram A, Park ST, et al: Proximal events in signaling by plasma membrane estrogen receptors. J Biol Chem 2003, 278(4):2701-2712.

48. Chen Z, Yuhanna IS, Galcheva-Gargova Z, et al: Estrogen receptor alpha mediates the nongenomic activation of endothelial nitric oxide synthase by estrogen. J Clin Invest 1999, 103(3):401-406.

49. Mendelsohn ME, Karas $\mathrm{RH}$ : The protective effects of estrogen on the cardiovascular system. N Engl J Med 1999, 340:1801-1811.

50. Kahlert $S$, Nuedling $S$, van Eickels $M$, et al: Estrogen receptor alpha rapidly activates the IGF-1 receptor pathway. J Biol Chem 2000, 275:18447-18453.

51. Castiglione F, Taddei A, Degl'Innocenti DR, et al: Expression of estrogen receptor beta in colon cancer progression. Diagn Mol Pathol 2008, 17(4):231-236

52. Barone M, Scavo MP, Papagni S, et al: ERbeta expression in normal, adenomatous and carcinomatous tissues of patients with familial adenomatous polyposis. Scand J Gastroenterol 2010, 45(11):1320-1328.

doi:10.1186/1423-0127-18-61

Cite this article as: Hsu et al:: JNK suppression is essential for $17 \beta$ Estradiol inhibits prostaglandin E2-Induced UPA and MMP-9 expressions and cell migration in human LoVo colon cancer cells. Journal of Biomedical Science 2011 18:61.

\section{Submit your next manuscript to BioMed Central and take full advantage of:}

- Convenient online submission

- Thorough peer review

- No space constraints or color figure charges

- Immediate publication on acceptance

- Inclusion in PubMed, CAS, Scopus and Google Scholar

- Research which is freely available for redistribution

Submit your manuscript at www.biomedcentral.com/submit
C) Biomed Central 